\title{
The 30-kD subunit of mammalian cleavage and polyadenylation specificity factor and its yeast homolog are RNA-binding zinc finger proteins
}

\author{
Silvia M.L. Barabino, Wolfgang Hübner, Andreas Jenny, ${ }^{1}$ Lionel Minvielle-Sebastia, and \\ Walter Keller ${ }^{2}$ \\ Department of Cell Biology, Biozentrum, University of Basel, CH-4056 Basel, Switzerland
}

\begin{abstract}
Cleavage and polyadenylation specificity factor (CPSF), a key component of the mammalian RNA 3'-end processing machinery, consists of four subunits of 160, 100, 73, and $30 \mathrm{kD}$. Here we report the isolation and characterization of a cDNA encoding the 30-kD polypeptide. Antibodies raised against this protein inhibit cleavage and polyadenylation and coimmunoprecipitate the other CPSF subunits. The protein sequence contains five $\mathrm{C}_{3} \mathrm{H}$-zinc-finger repeats and a putative RNA-binding zinc knuckle motif at the carboxyl terminus. Consistent with this observation, the in vitro translated $30-\mathrm{kD}$ protein binds RNA polymers with a distinct preference for poly(U). In addition, an essential $S$. cerevisiae gene, $Y T H 1$, was cloned which is $40 \%$ identical to CPSF $30 \mathrm{~K}$ at the protein level. Extracts prepared from a conditional yth1 mutant have normal cleavage activity, but fail to polyadenylate the upstream cleavage product. Efficient polyadenylation activity can be restored by the addition of purified polyadenylation factor I (PF I). We demonstrate that Yth1p is a component of PF I that interacts in vivo and in vitro with Fip1p, a known PF I subunit.
\end{abstract}

[Key Words: Pre-mRNA processing; cleavage and polyadenylation specificity factor; polyadenylation factor I; yeast; zinc finger, zinc knuckle]

Received February 4, 1997; accepted in revised form May 8, 1997.

Mammalian nuclear pre-mRNA $3^{\prime}$-end processing occurs in a two-step reaction that involves endonucleolytic cleavage of the precursor RNA at the cleavage site, usually located -15 nucleotides downstream of the AAUAAA signal, followed by the addition of a poly(A) tail to the upstream $\left(5^{\prime}\right)$ cleavage product. In vivo, the two reactions are coupled tightly. A major goal of investigating the mechanism of pre-mRNA 3'-end processing is the identification and functional characterization of the different trans-acting factors involved in the reaction. In mammals, several factors are required for $3^{\prime}$-end processing. The cleavage stimulation factor $(\mathrm{CstF})$ and the cleavage factors $\left(C F I_{m}\right.$ and $\left.C F I_{m}\right)$ are required for the cleavage reaction only, whereas poly(A) polymerase (PAP) and the cleavage and polyadenylation specificity factor (CPSF) participate in both steps (Takagaki et al. 1989; Rüegsegger et al. 1996; for review, see Wahle and Keller 1996). The efficiency of the polyadenylation reaction is increased in the presence of poly(A)-binding protein II (PAB II) (Wahle 1991).

\footnotetext{
${ }^{1}$ Present address: Differentiation Programme, European Molecular Biology Laboratory, Heidelberg, D-69117 Germany.

${ }^{2}$ Corresponding author.

E-MAIL Keller2@ubaclu.unibas.ch; FAX 41-61-267-2079.
}

CPSF has been purified from calf thymus and HeLa cells (Bienroth et al. 1991; Murthy and Manley 1992). It has a native molecular mass of $\sim 500 \mathrm{kD}$ and consists of four subunits of $160,100,73$, and $30 \mathrm{kD}$. UV cross-linking experiments with HeLa cell nuclear extract or partially purified CPSF fractions have shown that two proteins of 160 and $30 \mathrm{kD}$ interact with a substrate containing a functional AAUAAA polyadenylation signal (Gilmartin and Nevins 1991; Keller et al. 1991; Jenny et al. 1994). Because it has recently been reported that purified recombinant CPSF 160K binds to AAUAAA containing pre-mRNA (Murthy and Manley 1995), the possibility exists that the $30-\mathrm{kD}$ polypeptide may correspond to the smallest CPSF subunit. However, active CPSF preparations have been reported that do not appear to contain a $30-\mathrm{kD}$ polypeptide (Murthy and Manley 1992; Gilmartin et al. 1995). Therefore, the identity of this protein as well as its role in $3^{\prime}$-end processing remained to be elucidated.

In spite of a general similarity to higher eukaryotes, the mechanism of pre-mRNA $3^{\prime}$-end formation in yeast differs in a number of aspects. Only four factors have been shown to be required in this system: poly(A) polymerase (Paplp), the cleavage factors CF $\mathrm{I}_{\mathrm{y}}$ and $\mathrm{CF} \mathrm{II}_{\mathrm{y}}$, and the polyadenylation factor I (PF I) /Chen and Moore 
1992). In contrast to mammals, Paplp appears to be dispensable for the cleavage step; instead, cleavage requires the cleavage factors $C F I_{y}$ and $C F I_{y}$. Specific polyadenylation occurs in the presence of Palp, CF $I_{y}$, and PF I. Both CF $\mathrm{I}_{\mathrm{y}}$ and PF I are multisubunit protein factors. Two CF $\mathrm{I}_{\mathrm{y}}$ components are encoded by the genes RNA14 and RNA15 (Minvielle-Sebastia et al. 1994). Interestingly, these proteins have low but significant sequence similarity to mammalian 3 '-end processing factors. Rna14p shows $24 \%$ identity to the $77-\mathrm{kD}$ subunit of CstF and the RNA-binding domain of Rna15p is $42.5 \%$ identical to the equivalent domain of the $64-\mathrm{kD}$ subunit of CstF (Takagaki and Manley 1994). The first PF I subunit to be identified was Fiplp, which was isolated in a two-hybrid screen as a factor interacting with Paplp (Preker et al. 1995). More recently a new gene, called YSH1, was demonstrated to encode another subunit of PF I. This protein is $53 \%$ identical to the $73-\mathrm{kD}$ subunit of mammalian CPSF and represents its homolog in yeast (Chanfreau et al. 1996; Jenny et al. 1996).

In this paper we report the isolation of cDNAs encoding the $30-\mathrm{kD}$ subunit of bovine CPSF. We show that the $30-\mathrm{kD}$ polypeptide, which contains six putative zincbinding motifs, is required for both steps of $3^{\prime}$-end processing and binds RNA homopolymers. Furthermore, we have identified and cloned an essential yeast gene coding for a protein that contains considerable structural and functional similarity to the $30-\mathrm{kD}$ polypeptide. We also demonstrate that this protein is required for polyadenylation and is a subunit of PF I.

\section{Results}

The CPSF 30-kD subunit is required for in vitro cleavage and polyadenylation

To isolate a cDNA encoding the $30-\mathrm{kD}$ subunit, CPSF was purified from calf thymus according to Bienroth et al. (1991), separated on a preparative SDS-polyacrylamide gel and blotted on polyvinylidifluoride (PVDF). The protein was digested with trypsin in situ and the resulting peptides were purified by reversed-phase highpressure liquid chromatography (HPLC) and sequenced. Only two sequences were obtained, which were used to search databanks (T21 and T9; see Materials and Methods). The search resulted in the identification of a human infant brain clone of 1340 bp encoding a protein that contains both tryptic fragments (NIB2101, GenBank accession no. T16984). With a 480-bp HindIII-PVuII fragment of this cDNA, we screened a bovine aorta library and obtained three clones. The longest cDNA codes for a 243-amino-acid protein with a predicted molecular mass of $31 \mathrm{kD}$. The protein contains five putative zinc-binding repeats of the form $\mathrm{C}-\mathrm{X}_{7}-\mathrm{C}-\mathrm{X}_{5}-\mathrm{C}-\mathrm{X}_{3}-\mathrm{H}$ (DuBois et al. 1990) and a carboxy-terminal "zinc knuckle" of the type $\mathrm{C}-\mathrm{X}_{2}-\mathrm{C}-\mathrm{X}_{4}-\mathrm{H}-\mathrm{X}_{4}-\mathrm{C}$, first described in retroviral nucleocapsid proteins (Berg and Shi 1996). Homology searches in different databanks revealed that the putative $30-\mathrm{kD}$ subunit of CPSF shares remarkable homology to a Danio rerio mRNA encoding the no arches protein $188 \%$ iden- tity, 93\% similarity; Gaiano et al. 1996), to the Drosophila melanogaster Clipper protein $163 \%$ identity, $78 \%$ similarity; Bai and Tolias 1996), to the Caenorhabditis elegans open reading frame (ORF) F11A10.3 (49\% identity, $64 \%$ similarity; GenBank accession no. Z68297) and finally to a putative Saccharomyces cerevi. siae protein $(40 \%$ identity, 60.5\% similarity; YPR107c, GenBank accession no. U32445). As shown in Figure 1A, all these proteins share the same five $\mathrm{C}_{3}-\mathrm{H}$ repeats and highly conserved spacing between the single zinc fingers. The zinc knuckle domain at the carboxyl terminus, however, is located at variable distances from the last zinc finger in the different proteins. Figure $1 \mathrm{~B}$ shows the alignment of the amino acid sequences of the CPSF 30$\mathrm{kD}$ subunit and of its yeast homolog, termed Ythlp (yeast thirty $\mathrm{kD}$ homolog). The sequence conservation in the central part of the two proteins is remarkable $147.9 \%$ identity in a 142-amino-acid overlap). Interestingly, the zinc knuckle motif is missing from the yeast polypeptide.

To elucidate the role of the $30-\mathrm{kD}$ polypeptide in $3^{\prime}$ end processing, we raised polyclonal antibodies against the recombinant protein. A cDNA fragment encoding the entire bovine ORF was cloned into an Escherichia coli expression vector. The resulting recombinant protein was purified and used to generate rabbit polyclonal antibodies. The serum specifically recognized a protein of the predicted size on a Western blot of unfractionated calf thymus extract as well as of HeLa nuclear extract (Fig. 2). The band corresponding to the $30-\mathrm{kD}$ protein decreased in size in the pure CPSF fraction (Bienroth et al. 1991), probably attributable to proteolytic degradation of the full-length polypeptide. However, some fulllength protein was still present in this fraction (Fig. 2, lane 7|. To confirm that this protein corresponds to CPSF $30 \mathrm{~K}$, the antiserum was used to immunodeplete both a HeLa cell nuclear extract and a partially purified CPSF fraction (DEAE pool; Bienroth et al. 1991). The depleted extract was then tested for cleavage (Fig. 3A) and for specific polyadenylation activity (Fig. 3B). Preincubation of the extract with preimmune serum coupled to protein A-sepharose (Fig. 3A, lane 3) did not affect cleavage when compared with untreated extract (Fig. 3A, lane 2). In contrast, cleavage activity in HeLa nuclear extract immunodepleted with anti-30K antiserum was reduced significantly (Fig. 3A, lane 4). A partial restoration of activity could be obtained by addition of purified CPSF (Fig. 3A, lanes 5,6$)$, indicating that CPSF alone is not sufficient to restore a normal level of cleavage activity to the immunodepleted extract. This result suggests that other 3 '-end processing factors required for cleavage are coimmunodepleted along with CPSF and is consistent with the interaction observed in vitro between recombinant CPSF $160 \mathrm{~K}$ and the $77-\mathrm{kD}$ subunit of CstF (Murthy and Manley 1995).

A similar inhibition of activity was observed when polyadenylation was assayed with the immunodepleted extract. Figure $3 \mathrm{~B}$ shows a polyadenylation assay performed with a pool of calf thymus DEAE fractions. As shown in lanes 6 and 7 of Figure 3B, the sample immu- 


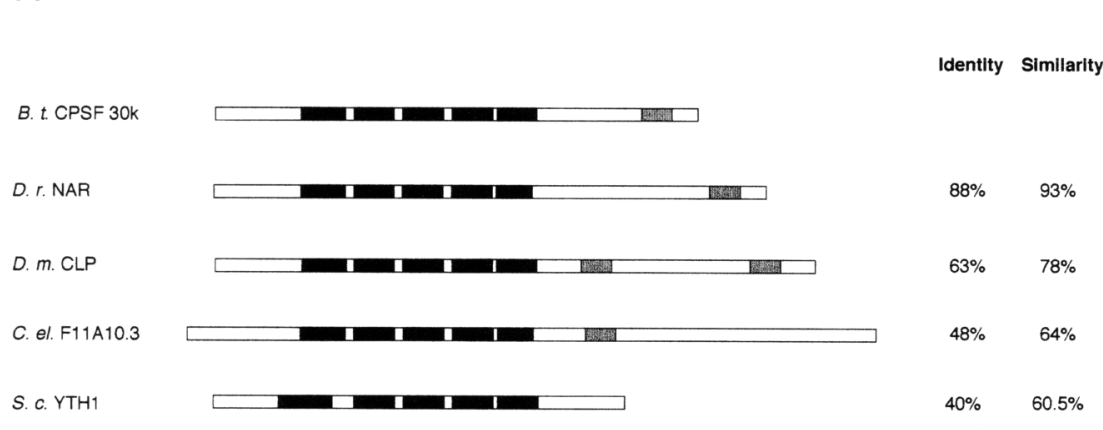

B

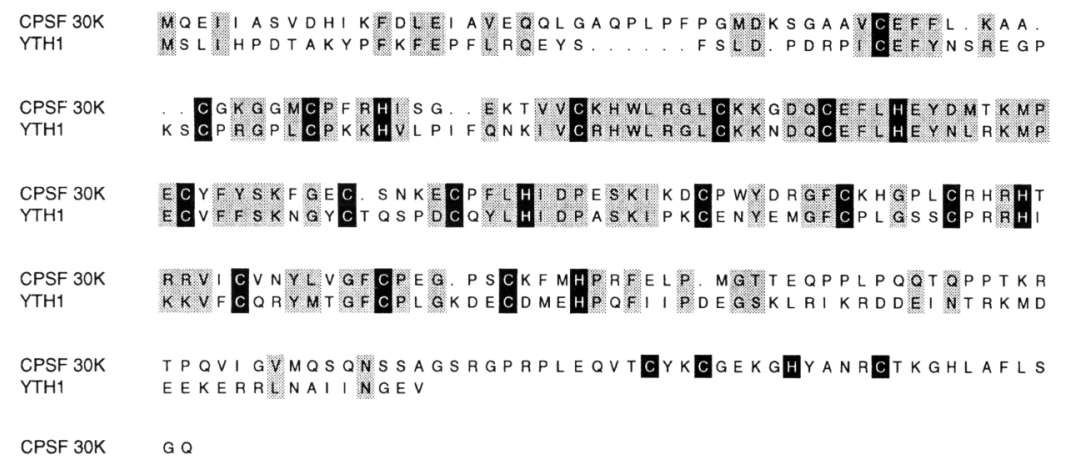

Figure 1. (A) Schematic alignment of CPSF $30 \mathrm{~K}$ and homologous protein sequences identified in the database. The five zinc finger domains are represented by black boxes, whereas the zinc knuckle motif is shown in gray. The alignment was generated with the program PILEUP. D. rerio no arches (D.r. NAR; Gaiano et al. 1996), D. melanogaster clp (D.m. CLP; Bai and Tolias 1996), C. elegans F11A10.3 (C. el. F11A10.3; GenBank accession no. Z68297). (B) Homology between CPSF 30$\mathrm{kD}$ subunit and YTH1. Amino acid sequence alignment of the bovine CPSF 30 $\mathrm{kD}$ subunit (GenBank accession no. U96448) and of its yeast homolog YTH1 (YPR107c). The alignment was generated from the TFASTA and the PILEUP programs. The cysteine and histidine residues of the zinc finger motifs are indicated in white on black; the other conserved residues are boxed in gray. nodepleted with the anti-30K antiserum was devoid completely of any CPSF activity, whereas the mock-depleted sample showed polyadenylation activity comparable with the untreated calf thymus fraction (Fig. 3B, cf. lanes 4 and 5 with lanes 2 and 3). Upon addition of purified CPSF, polyadenylated RNA was produced in amounts comparable with the mock-depleted sample (Fig. 3B, lanes 8 and 9). A Western blot of the proteins immunoprecipitated by the anti-30K serum showed coimmunoprecipitation of the three other CPSF subunits (Fig. 3C, lane 4), therefore confirming the tight association of the $30-\mathrm{kD}$ polypeptide with the other CPSF components. These results are consistent with the expected behavior of a true subunit of CPSF.

The yeast homolog of CPSF $30 \mathrm{~K}$, Yth1p, is an essential $3^{\prime}$-end processing factor required for polyadenylation

The yeast ORF on chromosome XVI identified in the databank search shows $40 \%$ identity to the $30-\mathrm{kD}$ subunit of CPSF. Homologs identified previously of mammalian 3 '-end processing factors in yeast have identity scores that range between $24 \%$ for Rna14p, the proposed yeast homolog of the $77-\mathrm{kD}$ subunit of CstF, and $47 \%$ in the case of Paplp, the yeast PAP. The recently cloned gene YSH1/BRR5 is $53 \%$ identical to CPSF $73 \mathrm{~K}$ (Chanfreau et al. 1996; Jenny et al. 1996). Based on these observations, this ORF represented a good candidate for a CPSF 30K homolog. A 660-bp DNA fragment was cloned by PCR that encodes a 208 -amino-acid protein with a predicted molecular mass of $24 \mathrm{kD}$. This fragment was expressed in E. coli and antibodies were raised against the fusion protein (see Materials and Methods). The antiYthlp antiserum recognized a protein of the predicted size on a Western blot of total yeast extract /data not shown).

To investigate the function of YTH1, we initially tested the requirement of the gene for viability. A construct in which the central portion of the ORF was substituted by the selectable TRP1 gene, was used to replace one YTH1 wild-type allele in a diploid strain by a onestep gene disruption. Southern blot analysis confirmed that correct replacement had occurred, and dissection of tetrads obtained by sporulating the diploid produced a segregation of two viable and two lethal spores. None of the viable spores was $\operatorname{Trp}^{+}$, indicating that the disruption of YTH1 is lethal. The lethal effect of YTH1 disruption was rescued by the PCR fragment cloned in an URA3marked expression vector (strain SB3).

To determine whether YTH1 is required in $3^{\prime}$-end processing, a conditional mutant was generated by introducing a frame shift at position 154 in the YTH1 ORF (see Materials and Methods). The plasmid carrying the mutation was used to transform SB3 cells. The tranformants were replica-plated on medium containing 5-fluoroorotic acid to select for the loss of the URA3 plasmid carrying the wild-type allele. This mutant allele (yth1-1), which lacks the last 55 amino acids, is deficient for growth at $37^{\circ} \mathrm{C}$ and grows slowly at $30^{\circ} \mathrm{C}$ on a medium containing $3 \%$ formamide. To determine the effect of the mutation 


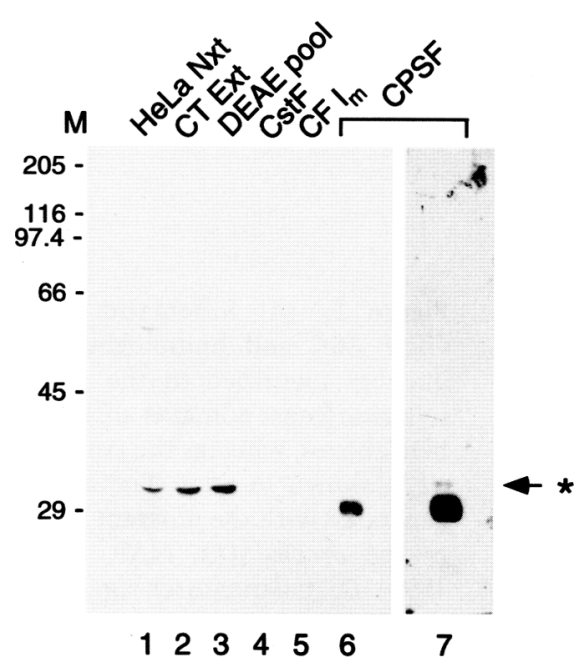

Figure 2. Antibodies to the recombinant $30-\mathrm{kD}$ protein recognize the smallest subunit of CPSF. Aliquots of HeLa cell nuclear extract (lane 1), calf thymus extract (lane 2), the DEAE pool (lane 3; Bienroth et al. 1991), a CstF poly(U) peak fraction (lane 4; Gunderson, et al. 1994), a CF I $\mathrm{I}_{\mathrm{m}}$ Mono Q peak fraction (lane 5; Rüegsegger et al. 1996), and of a CPSF gel filtration peak fraction (lanes 6,7; Bienroth et al. 1991) were separated on a $10 \%$ SDS-polyacrylamide gel and analyzed by immunoblotting according to standard procedures (Sambrook et al. 1989). The blot was probed with anti-30K antiserum at a dilution of 1:2000 and developed with the enhanced chemoluminescence kit (Amersham/. The band corresponding to the full-length $30 \mathrm{~K}$ protein present in lanes 1-3 is also visible on a longer exposure of lane 6 (lane 7) as indicated by the asterisk. The molecular mass of marker proteins in kilodaltons is indicated on the left (M).

on cleavage and polyadenylation, extracts were prepared from the yth1-1 temperature-formamide-sensitive (tfs) mutant cells and tested for the ability to process synthetic pre-mRNAs in vitro (Fig. 4). In the wild-type YTH1 extract, CYC1 pre-mRNA is cleaved and polyadenylated (Fig. 4, lane 2). In contrast, yth1-1 extract efficiently cleaves the pre-mRNA substrate but fails to polyadenylate the upstream cleavage product (Fig. 4, lane 3), showing a similar behavior as fip1-1 extract (Fig. 4, lane 4). Addition of fip1-1 mutant extract to yth1-1 mutant extract fails to restore polyadenylation (Fig. 4, lane 6). Efficient addition of a poly(A) tail to the upstream cleavage product can be obtained by mixing yth1-1 extract with rna14-1 extract, which by itself is unable to cleave and polyadenylate the substrate (Fig. 4, lane 7) (Minvielle-Sebastia et al. 1994). The in vitro phenotype of the conditional yth1-1 allele indicates that the protein is required for polyadenylation. The fact that an extract from a mutant allele of FIP1, encoding a component of PF I (Preker et al. 1995), is unable to complement the yth1-1 extract in vitro, strongly suggests that both proteins are nondissociable components of the same factor.

Yth1p is a component of PF I and directly interacts with Fip1p

To test the possibility that Ythlp may be a component of
PF I, we performed an immunoblot analysis of fractions of a MonoQ column and used antisera to Rna15p and Fiplp to identify CF I- and PF I-containing fractions (Fig. 5A). Affinity-purified anti-Ythlp antibodies detect a polypeptide corresponding in size to Yth $1 \mathrm{p}$, which perfectly comigrates with Fiplp (fractions 55 to 65). The association of Ythlp with PF I was confirmed by functional complementation of the polyadenylation defect in yth1-1 mutant extract (Fig. 5B). As shown above, yth1-1 extract can efficiently cleave $C Y C 1$ pre-mRNA but fails to polyadenylate the upstream cleavage product (Fig. $5 \mathrm{~B}$, lane 2). However, when pure PF I is added to the mutant extract, the amount of polyadenylated RNA produced is comparable with wild-type levels. Taken together these results demonstrate that Ythlp is an essential subunit of PF I.

Having established that Ythlp, like Fiplp, is an undissociable component of the PF I complex, the possibility that the protein can interact directly with other 3 '-end processing factors was investigated. For this reason coimmunoprecipitation experiments were performed with in vitro-translated, radio-labeled Yth $1 \mathrm{p}$ and recombinant Fip1, Pap1, Rna14, and Rna15 polypeptides (Fig. 6A). Total Ythlp in vitro translation reaction was added to protein A-Sepharose beads to which Rna14 and Rna15 (Fig. 6A, lane 3), Fip1 (Fig. 6A, lane 5) or Pap1 (Fig. 6A, lane 7) proteins were coupled by their specific antibodies. As shown in lane 5 of Figure 6A, only recombinant Fip1 protein coupled to anti-Fiplp antibodies could coimmunoprecipitate $Y$ th $1 p$, indicating that the two proteins can interact directly.

The yeast two-hybrid system, which allows the detection of protein-protein interactions in vivo, was used to verify the result of the coimmunoprecipitation assay (for review, see Fields and Sternglanz 1994). Plasmids with the entire YTH1 ORF, fused to either the DNA-binding domain (pAS2-YTH1) or the transcription activation domain of the yeast GAL4 protein (pACT2-YTH1) (see Materials and Methods) were constructed and used to transform Y187 and CG1945 cells. The transformants were then mated. The interaction of Yth1 with Fipl proteins was measured in the diploid cells by activation of HIS3 and $l a c Z$ reporter constructs as detected by growth on a medium lacking histidine (Fig. $6 \mathrm{~B}$ ) and $\beta$-galactosidase activity assay (Fig. $6 \mathrm{C}$ ), respectively. The interaction between Fipl and Pap1 proteins was used as a positive control (Preker et al. 1995). Diploid cells expressing both Ythlp and Fiplp (pAS2-YTH1/pACT2-Fip1) can grow on a medium lacking histidine, suggesting a strong interaction between the two proteins. This result is confirmed by the $\beta$-galactosidase assay: the activity is comparable with that detected for the Fiplp/Paplp heterodimer.

RNA-binding ability of the CPSF $30 \mathrm{~K}$ is enhanced by the zinc knuckle motif

An examination of the amino acid sequence of CPSF $30 \mathrm{~K}$ and $Y$ th $1 p$ reveals the presence of five repeats that show striking homology to the putative zinc-binding domain 

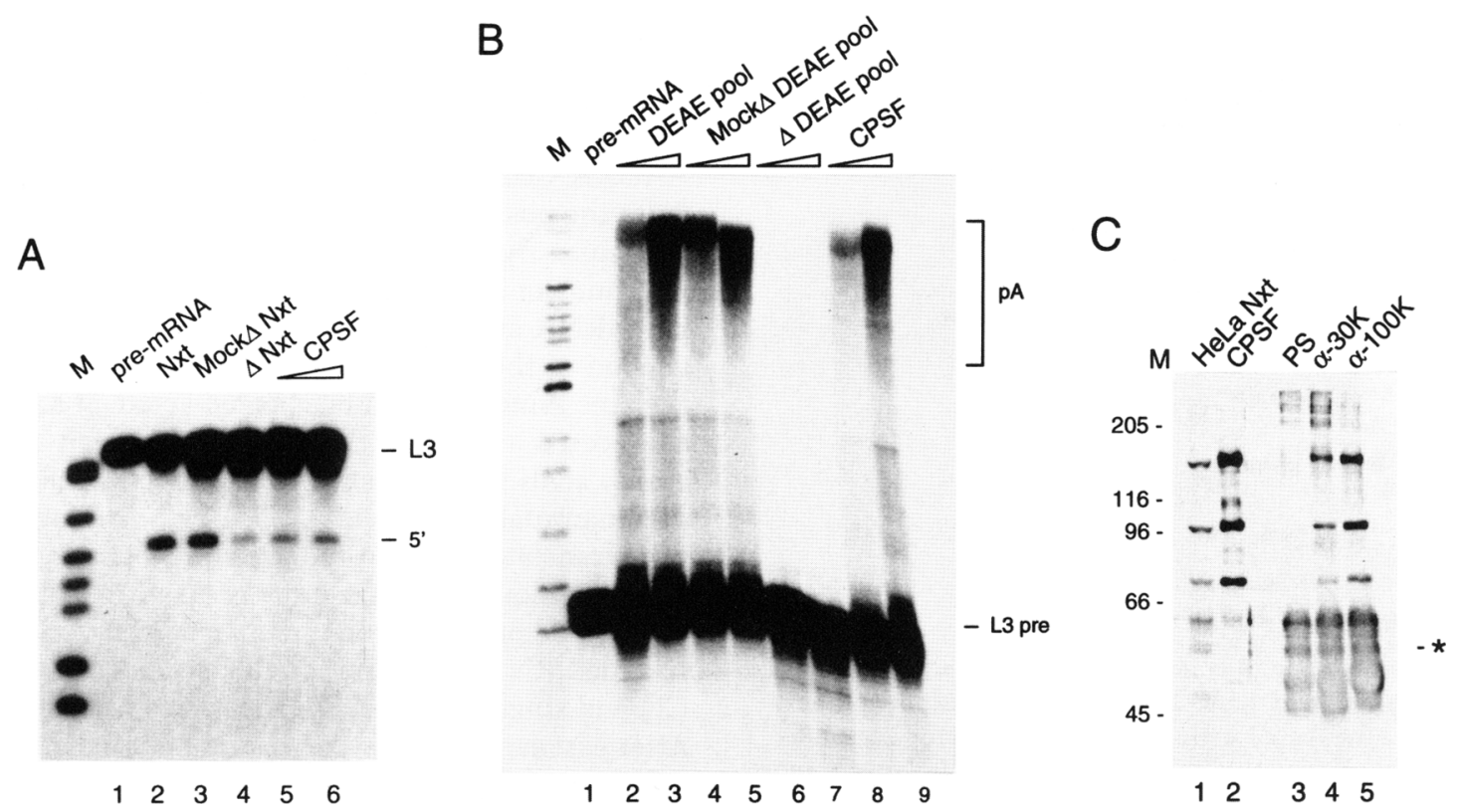

Figure 3. Immunodepletion of CPSF activity with anti-30K antibodies inhibits cleavage and polyadenylation of pre-mRNA. $(A)$ Cleavage of L3 pre-mRNA. HeLa cell nuclear extract was preincubated with either anti-30K antibodies (lanes 4-6) or preimmune serum (lane 3). The cleavage reaction was carried out for $1 \mathrm{hr}$ at $30^{\circ} \mathrm{C}$ under standard conditions (see Material and Methods); the reaction products were separated on a $6 \%$ denaturing polyacrylamide gel. (Lane 2) Cleavage reaction performed with $4 \mu \mathrm{l}$ of untreated nuclear extract. (Lane 3) Nuclear extract $(6 \mu 1)$ pre-incubated with pre-immune serum. (Lane 4) Nuclear extract $(6 \mu l)$ depleted with anti-30K antibodies. (Lanes 5,6$)$ Cleavage activity was rescued by the addition of increasing amounts $(35$ and 70 fmoles, respectively) of pure CPSF to $6 \mu \mathrm{l}$ of depleted extract. (B) Polyadenylation of precleaved L3 pre-mRNA. A CPSF pool of calf thymus DEAE fractions was immunodepleted either with anti-30K antibodies (lanes 6-9) or preimmune serum (lane 4,5). The polyadenylation reaction was performed for $30 \mathrm{~min}$ at $30^{\circ} \mathrm{C}$ under standard conditions (see Materials and Methods); the reaction products were separated on a $12 \%$ denaturing polyacrylamide gel. (Lanes 2,3$)$ Polyadenylation reactions with increasing amounts of untreated CPSF pool (0.5 $\mu 1$ and $1 \mu l$, respectively). (Lane 3,4 One microliter and $2 \mu \mathrm{l}$ of CPSF pool pre-incubated with pre-immune serum. (Lanes 6,7) One and two microliters of CPSF pool depleted with anti-30K antibodies. (Lanes 8,9) Two microliters of depleted CPSF pool was complemented with increasing amounts of pure CPSF ( 14 and 28 fmoles, respectively). The position of the full-length RNA substrate (lane 1), the upstream cleavage product $\left(5^{\prime}\right)$ and of the polyadenylated mRNA $(\mathrm{pA})$ are indicated. Markers are end-labeled HpaII-digested pBR322 fragments (M). (C) Antibodies against the $30-\mathrm{kD}$ protein coprecipitate the three larger CPSF subunits. HeLa cell nuclear extract was subjected to immunoprecipitation with the indicated sera (lanes 3-5). The eluates were fractionated on a $8 \%$ SDS-polyacrylamide gel and analyzed by immunoblotting (for details, see Materials and Methods). The blot was probed with anti-70K (dilution 1:8000; Jenny et al. 1996), anti-100K (dilution 1:10000; Jenny et al. 1994) and affinity-purified anti-160K antibodies (dilution 1:50). (Lane 1) HeLa cell nuclear extract; (lane 2) highly purified CPSF [poly(A)-Sepharose pool; Bienroth et al. 1991]; (lane 3) preimmune serum; (lane 4) anti-30K antibodies; (lane 5) anti-100K antibodies. The antibodies' heavy chains are indicated by the asterisk. The molecular mass of marker proteins in kilodaltons is indicated on the left $(\mathrm{M})$.

of the $\mathrm{C}_{3} \mathrm{H}$-type first described in the mouse growthfactor inducible nuclear protein Nup475/TIS-II (DuBois et al. 1990), but also identified in the splicing factor U2AF35 (Zhang et al. 1992) and in the Drosophila genes unkempt (Mohler et al. 1992) and suppressor of sable [su(s); Voelker et al. 1991; Fridell and Searles 1994]. More recently, the same motif has been described in the C. elegans protein PIE-1 (Mello et al. 1996). The alignment of these zinc finger repeats is shown in Figure 7A. The role of the cysteine-rich motif is unknown, but its presence in protein factors that interact with nucleic acids suggests a possible direct involvement in RNA binding. In addition to the five zinc fingers, the bovine protein also contains at its carboxyl terminus another putative zinc-binding domain similar to the zinc knuckle motif of retroviral nucleocapsid proteins (Fig. 7B). In retroviruses, the nucleocapsid proteins are asso- ciated with genomic RNA, and mutations within the zinc knuckle motif, particularly of the conserved cysteine residues, abolish the packaging of genomic RNA into viral particles (South et al. 1990). Zinc knuckle repeats have been found in the mammalian CNBP protein (Rajavashisth et al. 1989) that binds to the sterol regulatory element and also in some splicing factors such as the mammalian proteins SF1 (Arning et al, 1996) and 9G8 (Cavaloc et al. 1994), and the yeast factor SLU7 (Frank and Guthrie 1992). Based on the results of the mutagenesis experiments in the viral system, it has been suggested that the zinc knuckle has a critical role in mediating specific RNA interaction. However, mutations in two of the conserved cysteine residues of the SLU7 zinc knuckle had only a minor effect on in vitro $3^{\prime}$-splice-site selection (Frank and Guthrie 1992). 


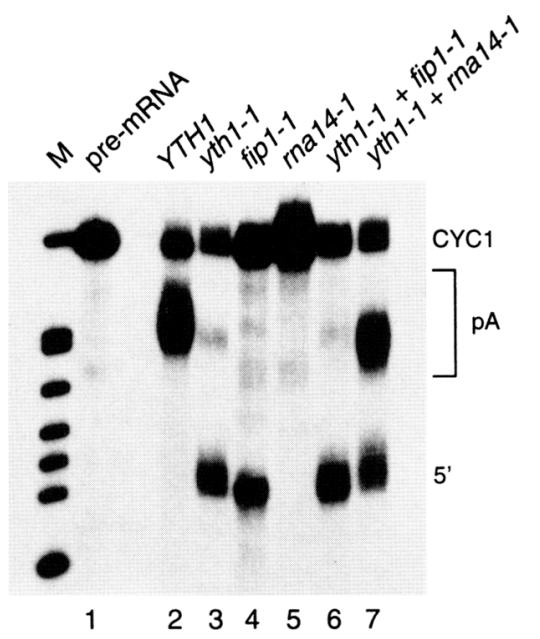

Figure 4. Cleavage and polyadenylation in mutant yth1-1 extract. Wild-type extract (lane 2) or different mutant extracts (lanes 3-5) were incubated with CYC1 pre-mRNA for $1 \mathrm{hr}$ under standard conditions (see Materials and Methods). In lanes 6 and $7,3 \mu$ l of $y$ th 1-1 mutant extract were mixed with equal amounts of either fip1-1 or rna14-1 mutant extracts. The position of the full-length RNA substrate (lane 1), the upstream cleavage product $\left(5^{\prime}\right)$ and of the polyadenylated mRNA (pA) are indicated. Markers are end-labeled HpaII-digested pBR322 fragments (M).

The presence of a putative RNA-binding motif in the sequence of CPSF $30 \mathrm{~K}$ was not entirely surprising as it had been shown previously that CPSF can specifically bind to an AAUAAA-containing RNA (Keller et al. 1991). Furthermore, two proteins of $160 \mathrm{kD}$ and of 30 $\mathrm{kD}$, respectively, can be specifically cross-linked to the substrate RNA by UV irradiation and immunoprecipi- tated with a monoclonal antibody that recognizes the $100-\mathrm{kD}$ subunit of CPSF (Jenny et al. 1994). More recently, Murthy and Manley (1995) have shown that the recombinant $160-\mathrm{kD}$ subunit binds preferentially to an AAUAAA-containing RNA. We therefore wanted to address the possibility that the zinc-binding motifs, and in particular the zinc knuckle, which is present in CPSF $30 \mathrm{~K}$ but not in Ythlp, could have a role in binding the pre-mRNA substrate. To test this possibility, a mutant version of the $30-\mathrm{kD}$ protein was constructed in which the zinc knuckle motif has been deleted (30K $\Delta$ ). We also engineered a fusion Yth1 protein in which the last 18 amino acids were replaced by the zinc knuckle motif of the mammalian protein (YTHl-zk). All four proteins were translated in vitro and used for RNA-binding assays (Fig. 7C). Equivalent amounts of in vitro-translated, radio-labeled proteins were incubated with various singlestranded RNA polymers, double-stranded RNA [poly|I/ C)], and single-stranded DNA coupled to a solid matrix. After extensive washes, the bound radio-labeled proteins were eluted in protein sample buffer and fractionated on an SDS-polyacrylamide gel. As shown in Figure 7C, CPSF $30 \mathrm{~K}$ binds to poly(U), and to a minor extent, to poly $(\mathrm{G})$. The deletion of the zinc knuckle motif dramatically decreases its ability to bind poly(U) (Fig. 7C, lanes $12,13)$. On the other hand, Ythlp shows a slight affinity for poly(U) alone (Fig. 7C, lane 18); the fusion of the zinc knuckle motif, however, substantially increases its binding to poly(U) (Fig. 7C, lane 24). The results of three independent binding experiments are summarized in Figure 7D. From these experiments we conclude that CPSF $30 \mathrm{~K}$ and its yeast homolog are RNA-binding proteins. In the case of CPSF $30 \mathrm{~K}$, its ability to interact with RNA, and in particular with poly(U), is mediated in the

A

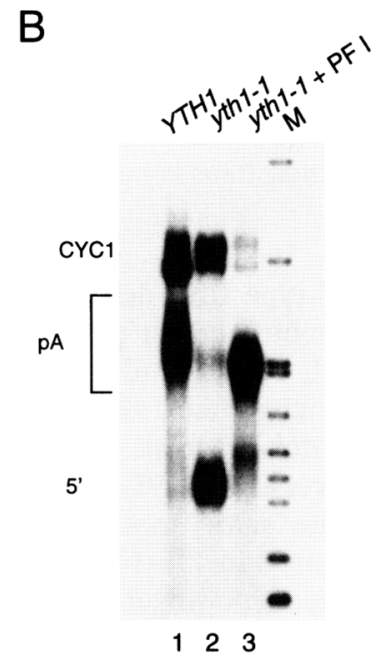

Figure 5. Ythlp is a subunit of PFI. $|A|$ Anti-Yth $1 \mathrm{p}$ antibodies detect Ythlp in PF I-containing column fractions. Four microliters of MonoQ gradient fractions were fractionated on a 12\% SDS-PAGE, blotted on nitrocellulose, and probed with anti-Rna15p (1:15000), anti-Fiplp (affinity purified, 1:2000) and anti-Ythlp (affinity purified, 1:2000) antibodies. (B) Complementation of polyadenylation activity of yth1-1 mutant extract with pure PF I. Wild-type YTH1 (lane 1) and yth1-1 (lane 2) mutant extracts were incubated with precursor RNA under standard conditions. In lane 3, yth1-1 extract is complemented with $1 \mathrm{ml}$ of a pure PF I fraction. The position of upstream cleavage product $\left(5^{\prime}\right)$ and of the polyadenylated mRNA (pA) are indicated. Markers are end-labeled HpaII-digested pBR322 fragments (M). 
A

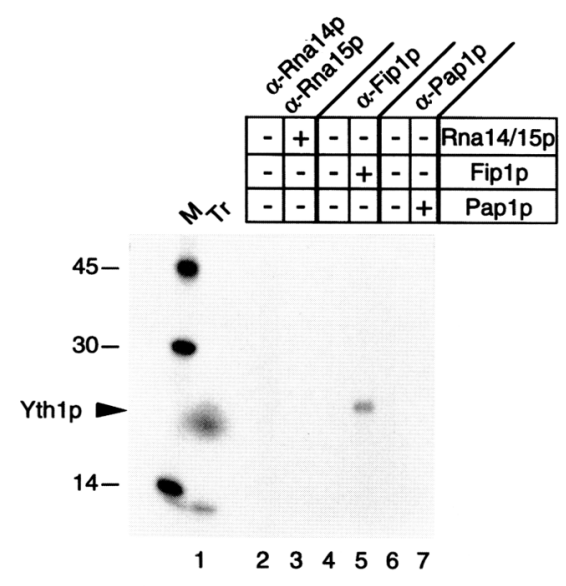

C

\begin{tabular}{ccc}
\hline $\begin{array}{c}\text { Peptide fused to GAL4 } \\
\text { activation domain }\end{array}$ & $\begin{array}{c}\text { Peptide fused to GAL4 } \\
\text { binding domain }\end{array}$ & $\begin{array}{c}\text { B-galactosidase activity } \\
\text { (units) }\end{array}$ \\
\hline FIP1 & YTH1 & $162.7 \pm 24.9$ \\
YTH1 & YTH1 & $0.8 \pm 0.3$ \\
PAP1 & YTH1 & $<0.1$ \\
FIP1 & PAP1 & $124.1 \pm 21.3$ \\
YTH1 & none & $1.0 \pm 0.5$ \\
none & YTH1 & $<0.1$ \\
FIP1 & none & $<0.1$ \\
none & FIP1 & $0.3 \pm 0.1$ \\
PAP1 & none & $<0.1$ \\
\hline
\end{tabular}

B
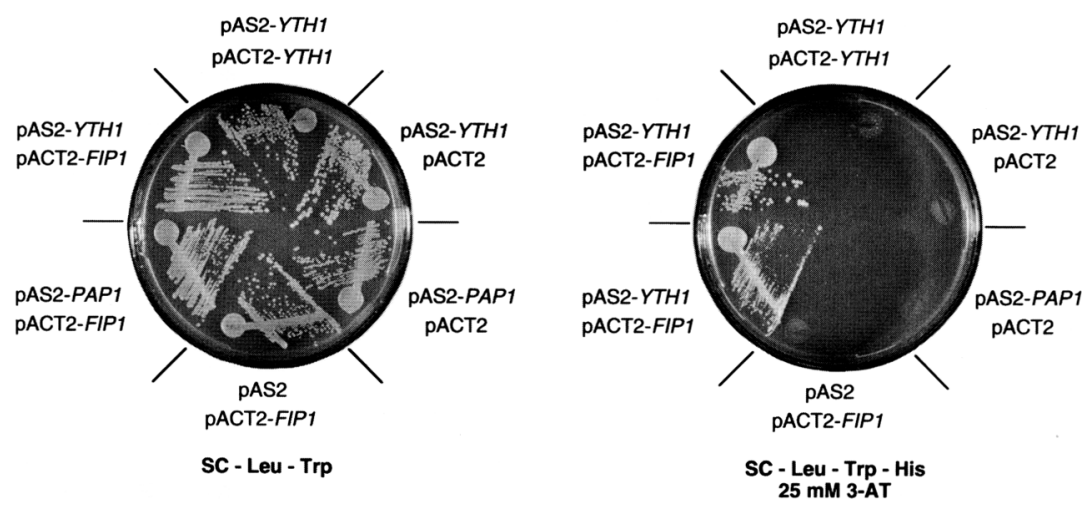

Figure 6. Yth 1 protein physically interacts with Fiplp in vitro and in vivo. (A) In vitro-translated Yth1p interacts directly with recombinant Fipl protein. In vitro-translated, radiolabeled Ythlp was incubated with anti-Rnal4p and Rna15p, anti-Fip1p and anti-Paplp antibodies coupled to protein A-Sepharose beads, either in the presence or in the absence of the corresponding recombinant protein as described in Materials and Methods. The immunoprecipitated proteins were resuspended in protein sample buffer, fractionated on a $12 \%$ SDS-PAGE and visualized by autoradiography. (Lane 1) Ythlp in vitro translation reaction ( $\mathrm{Tr}$ ). Markers are ${ }^{14} \mathrm{C}$-labeled proteins. (B) Interaction between Yth1 and Fip1 proteins in the two-hybrid system. Y187 and CG1945 cells were transformed with pAS2 (GAL4-binding domain, BD) and pACT2 (GAL4-activating domain, AD) harboring Yth1, Fip1, and Pap1 ORFs and mated. The diploid cells were grown on SC medium lacking leucine and tryptophane. The dimerization was tested for growth on a medium lacking leucine, tryptophane, and histidine but containing 3-aminotriazole. Three negative controls with the proteins fused to either the GAL4-BD or the GAL4-AD only are included. $(C)$ Interaction between Ythl and Fipl proteins measured by lacZ reporter-gene expression. Quantitative $\beta$-galactosidase assay was conducted on diploid cells expressing the designated constructs. Assays were done in multiples. Mean values and standard deviations are given in units (see Preker et al. 1995, for definition).

first place by the zinc knuckle motif, which alone contributes at least as much as the five zinc fingers to poly(U) binding (Fig. 7D). Nevertheless, the CPSF 30K deletion mutant and the Ythlp, both lacking this domain, still show a low affinity for poly(U), possibly attributable to the presence of the five zinc fingers.

\section{Discussion}

Previous work of our laboratory showed that pure CPSF consists of four polypeptides of $160,100,73$, and $30 \mathrm{kD}$ (Bienroth et al. 1991). However, active CPSF preparations lacking the $30-\mathrm{kD}$ polypeptide have been reported (Murthy and Manley 1992; Gilmartin et al. 1995). It was suggested that the CPSF $30 \mathrm{~K}$ might be a nonessential polypeptide, which is only loosely associated with the other CPSF subunits (Manley and Proudfoot 1994; Murthy and Manley 1995). Therefore, the identity and the function of this protein was unclear.

\section{The 30-kD polypeptide is an essential CPSF subunit}

Our results demonstrate the tight association of the 30$\mathrm{kD}$ protein with the other CPSF subunits. Antibodies raised against the recombinant protein deplete cleavage and polyadenylation activity in HeLa cell nuclear extract and coprecipitate the other CPSF subunits. Efficient $3^{\prime}$ end processing can be reconstituted by addition of pure CPSF. Databank searches led to the identification of a putative homolog of CPSF $30 \mathrm{~K}$ in $S$. cerevisiae. We cloned this gene, termed YTH1, and demonstrated that it is essential for cell viability and for polyadenylation. These results strongly suggest that the mammalian protein is also essential for polyadenylation. The observation that CPSF preparations lacking the $30-\mathrm{kD}$ subunit were active in in vitro 3 '-end processing may be explained by the fact that this polypeptide was in fact present in substochiometric amounts and therefore escaped detection.

Support for a crucial role of CPSF $30 \mathrm{~K}$ in gene expression has been provided by other in vivo observations. The developmentally regulated expression of the homologous Drosophila gene clipper (clp) suggests a role in RNA processing: $c l p$ transcripts are particularly abundant in the maternal germ line, consistent with a function in the regulation of the expression of maternal $\mathrm{mR}$ NAs that control crucial steps in early embryonic development. A second peak of $c l p$ transcripts is observed 
A

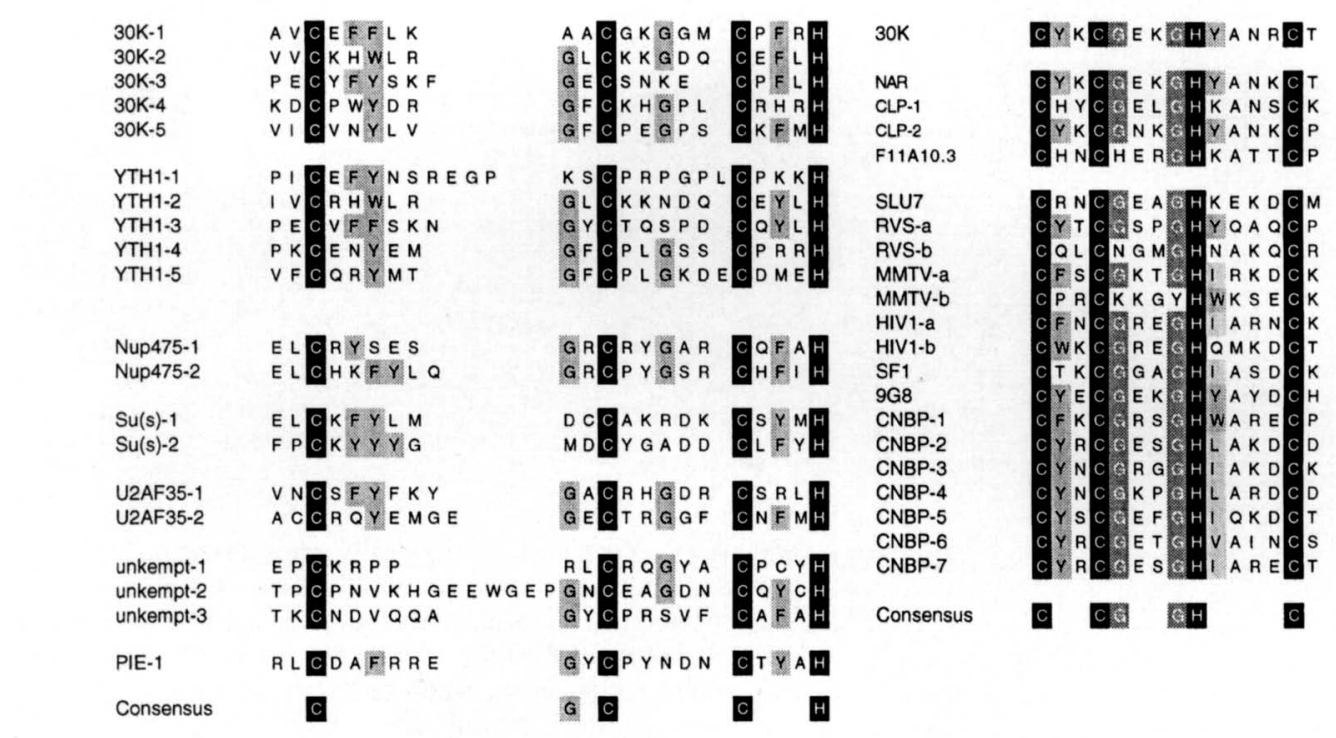

C

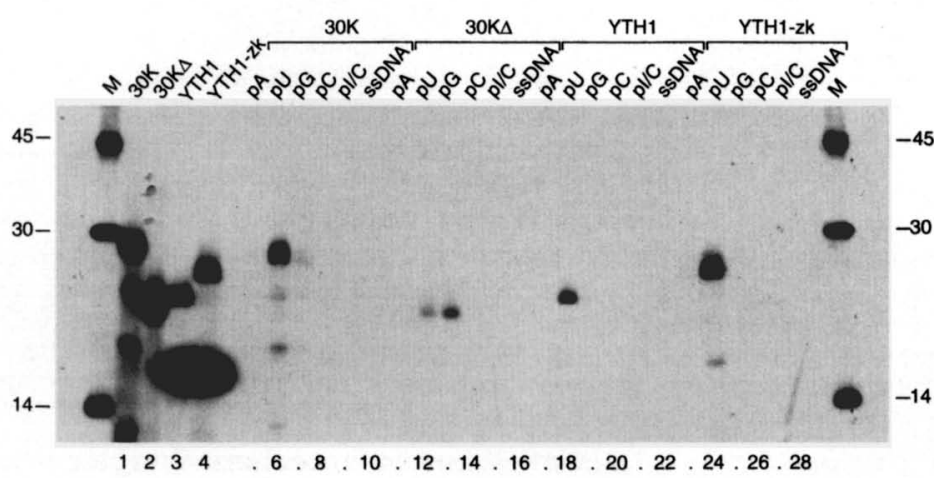

B

D

\begin{tabular}{lr}
\hline & $p(U)$ binding (\%) \\
\hline & \\
CPSF 30K & 100 \\
CPSF 30K $\triangle$ & 57 \\
YTH1 & 55 \\
YTH1-zk & 150 \\
\hline
\end{tabular}

Figure 7. The zinc-binding domains of CPSF $30 \mathrm{~K}$ and of Ythlp mediate RNA binding in vitro. (A) Alignment of the five zinc-finger repeats of CPSF $30 \mathrm{~K}$ and of Yth1 with proteins containing similar domains. The residues of the zinc finger motif are highlighted by black boxes, other conserved residues are indicted in grey. Nup475 (DuBois et al. 1990), D. melanogaster SU(s) (Voelker et al. 1991), D. melanogster unkempt (Mohler et al. 1992), C. elegans PIE-1 (Mello et al. 1996). (B) Alignment of the zinc knuckle motif of CPSF $30 \mathrm{~K}$ with other representative zinc knuckle-containing proteins. The residues of the zinc knuckle motif are highlighted by black boxes, the highly conserved glycines are indicated in white on grey, whereas other conserved residues are indicted in grey. $D$. rerio NAR (Gaiano et al. 1996), D. melanogaster CLP (Bai and Tolias 1996), C. elegans F11A10.3 (GenBank accession no. Z68297), S. cerevisiae SLU7 (Frank and Guthrie 1992), RVS (Schwartz et al. 1983), MMTV (Jacks et al. 1987), HIV (Wain-Hobson et al. 1985), SF1 (Arning et al. 1996), 9G8 (Cavaloc et al. 1994), CNBP (Rajavashisth et al. 1989). (C) RNA-binding assay with in vitro-translated proteins. Equivalent amounts of in vitro-translated, radio-labeled proteins were incubated with various RNA homopolymers and with singlestranded DNA coupled to Sepharose, as described in Materials and Methods. Bound proteins were eluted in protein sample buffer, fractionated on $12 \%$ SDS-PAGE, and visualized by autoradiography. (Lanes 1-4) Total in vitro translation reactions; (lanes 5-28) bound and eluted proteins. Markers are ${ }^{14} \mathrm{C}$-labeled proteins. $(D)$ The zinc knuckle motif enhances specific poly(U)-binding. The amount of recovered, ${ }^{35}$ S-labeled protein was quantified as described in Materials and Methods. The average binding of CPSF $30 \mathrm{~K}$ was defined as $100 \%$.

during late larval development, a time when the ecdysteroid-induced genes required for the larval-to-adult metamorphosis are transcribed (for review, see Ashburner 1990). The abundance of $c l p$ mRNA at times when developmentally relevant genes are actively transcribed is consistent with a function for this protein in gene expression. Also, the zebrafish homolog of CPSF $30 \mathrm{~K}$ was identified in a recent screen for essential genes (Gaiano et al. 1996). These findings, together with the lethal effect of the disruption of the homologous yeast gene, further support the essential function of this protein for cell viability. 


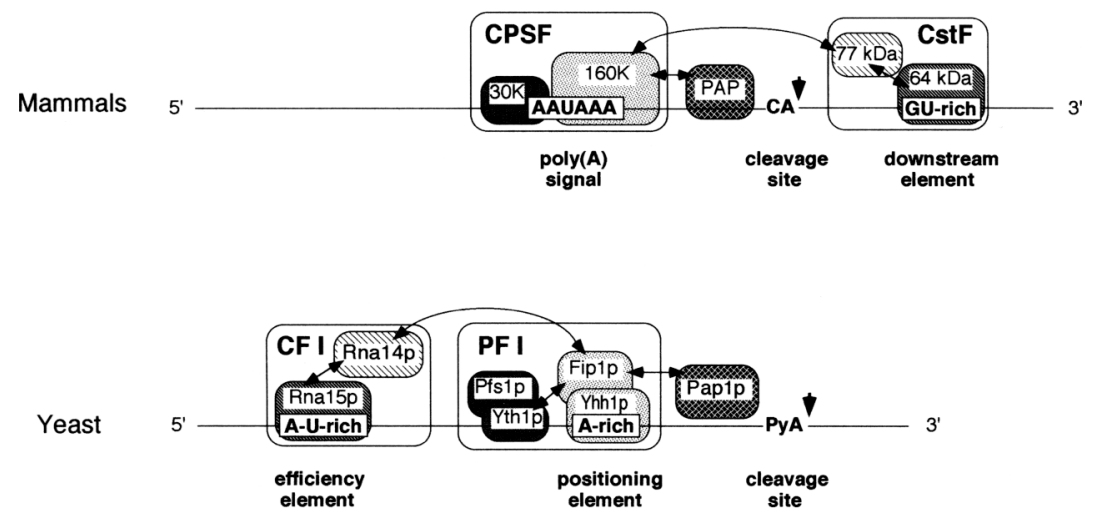

Figure 8. Conserved protein-protein interactions in the 3 '-end processing complex. Only those subunits, of the different yeast and mammalian 3 '-end processing factors, that participate in conserved interactions are shown. Whereas in the mammalian system the binding of the $64-\mathrm{kD}$ subunit of CstF with the downstream element and of CPSF $30 \mathrm{~K}$ and $160 \mathrm{~K}$ with the AAUAAA motif have been demonstrated, the interactions of the yeast proteins Rna15 and Yhh1 with the A-U-rich efficiency element and the A-rich positioning element, respectively, are speculative (Manley and Takagaki 1996). Homologous subunits are marked with the same grey pattern. The double-sided arrows indicate the demonstrated protein-protein interactions. The arrowheads demarcate the cleavage sites.
Evolutionary conserved protein-protein interactions in the 3 '-end processing complex

Although the general mechanism of $3^{\prime}$-end formation is conserved in lower and higher eukaryotes, the yeast poly(A) signals are different from those of mammalian genes (for review, see Guo and Sherman 1996). Mammalian signals are composed of the highly conserved AAUAAA signal, located upstream of the poly(A) site, and a downstream GU-rich element. Elements located upstream of the AAUAAA motif were shown recently to have a stimulatory but nonessential function in viral and in some mammalian genes (for reviews, see Wahle and Keller 1992, 1996; Wahle 1995). In yeast, the major determinants of the polyadenylation site are the A-rich positioning element, which can be AAUAAA, and the AUrich efficiency element, both located upstream of the poly(A) site. Apparently, no downstream element is present in yeast $3^{\prime}$-UTRs. Until recently, it was generally assumed that the mammalian and the yeast $3^{\prime}$-end processing machinery had to be significantly different from each other attributable to the different sequence requirements. However, evidence is accumulating that not only the genes but also the nature of the interactions between the different factors are largely conserved. Similarities can also be detected between yeast and mammalian cisacting sequences in the pre-mRNA (Fig. 8; for review, see Manley and Takagaki 1996).

Several protein-protein interactions between yeast $3^{\prime}$ end processing factors have been characterized (Fig. 8). It was demonstrated that PF I binds to CF I via Fiplp. In fact, a ternary complex can be formed between Fiplp, Paplp, and the CF I subunit Rnal4p (Preker et al. 1995). We have now shown that the PF I subunits Ythlp and Fiplp interact with each other both in vitro and in vivo. Furthermore, Rnal4p interacts biochemically and genetically with another CF I component, Rna15p (Minvielle-Sebastia et al. 1991, 1994). Rna14p and Rna15p represent the yeast homologs of the $77-$ and $64-\mathrm{kD}$ sub- units of mammalian CstF (Takagaki and Manley 1994). An interaction occurs in vitro between CPSF 160K and CstF 77- and 64-kD subunits (Murthy and Manley 1995). In view of the interaction between the CPSF 160K and the $77-\mathrm{kD}$ subunit of CstF on one hand, and Fiplp and Rna14p on the other, these authors postulated that Fiplp might correspond to the largest CPSF subunit. However, another PF I subunit, Yhh1p/Cftlp was cloned recently and shown to be $23.5 \%$ identical to CPSF 160K (Stumpf and Domdey 1996; Preker et al. 1997). Although Fiplp apparently does not bind to RNA, Yhhlp/Cftlp can be crosslinked, albeit very inefficiently, to RNA (P.J. Preker, unpubl.). Fiplp, on the other hand is not known to have a mammalian counterpart yet participates in similar interactions as CPSF $160 \mathrm{~K}$. Therefore, the functions of CPSF 160K may be split between two different yeast factors: Yhhlp, which contacts the pre-mRNA, and Fiplp, which interacts with Rna14p (Fig. 8).

Apparent differences exist between the functions of CPSF $30 \mathrm{~K}$ and Ythlp. As a subunit of CPSF, the $30 \mathrm{~K}$ protein is required for both cleavage and polyadenylation. In yeast, the factor that is functionally equivalent to CPSF is CF I, whereas the $30 \mathrm{~K}$ homolog Ythlp is a subunit of PF I and is only required for polyadenylation. However, both proteins bind RNA. Also, PF I contains all yeast homologs of the CPSF subunits and retains some of its functions (Preker et al. 1997). This result can be at least partially explained by the differences both in position and in sequence of the signals in the premRNA in yeast and in metazoans. We speculate that the subunits of mammalian and yeast $3^{\prime}$-end processing factors have evolved from common ancestor genes and have maintained similar functions even though they were redistributed differently in response to the divergent evolution of the pre-mRNA signals. Therefore, it appears that despite the apparent differences in the composition of the factors and in the signals required for RNA 3'-processing, the nature of the interactions between the components of the cleavage and polyadenyla- 
tion complex is conserved in lower and higher eukaryotes (Fig. 8).

\section{Cysteine/histidine repeats are involved in RNA binding}

Zinc finger proteins have been implicated in both DNA and RNA binding (South et al. 1990; Theunissen et al. 1992). We therefore investigated the possibility that the putative zinc binding domains, that is, the five aminoterminal zinc finger repeats and the zinc knuckle motif at the carboxyl terminus, present in CPSF $30 \mathrm{~K}$, could mediate its interaction with the pre-mRNA. Our results of RNA-binding experiments with in vitro-translated proteins are consistent with a role for these domains in RNA binding. CPSF $30 \mathrm{~K}$ exhibits binding to poly $/ \mathrm{U} /$ and, to a minor extent, to poly $(\mathrm{G})$ RNA homopolymers. Of the two different types of cysteine/histidine repeats, the zinc knuckle contributes the most for the poly(U) binding. The presence of two different RNA-binding domains is a frequent characteristic of RNA processing factors. Examples are the mammalian splicing factors SF1 (Arning et al. 1996) and 9G8 (Cavaloc et al. 1994) that contain either a KH-domain or an RNA recognition motif (RRM) and a zinc knuckle. A putative yeast homolog of SF1 was also identified that shares the KH-domain and two copies of the zinc knuckle. The conservation of these structural features suggests a role for the zinc knuckle motif in the recognition of single-stranded nucleic acids but also a requirement for co-operation of different RNA binding motifs to specify sequence-dependent interactions in vivo. Therefore, the possibility exists that the in vitro binding activity of CPSF $30 \mathrm{~K}$ and of its yeast homolog may not reflect the true in vivo specificity. This question will be the subject of further investigation.

The homologs of CPSF 30K in higher eukaryotes have either one or two copies of the zinc knuckle, as in the case of the Drosophila protein. Interestingly, this domain is absent in the yeast polypeptide. However, a zinc knuckle is found in Pfs $1 p$, a newly cloned PF I subunit (P.J. Preker, pers. comm.). This is further evidence for the hypothesis that distinct domains can be split in different polypeptides in yeast and be present on the same polypeptide in higher eukaryotes. The presence of an intron immediately preceding the exon encoding the zinc knuckle domain in C. elegans is consistent with rearrangements of independent protein domains by "exon shuffling" (Gilbert 1985; Doolittle and Stoltzfus 1993).

\section{Possible roles for CPSF $30 \mathrm{~K}$}

Recently, the $160-\mathrm{kD}$ subunit of CPSF was shown to recognize the AAUAAA polyadenylation signal, but the binding of recombinant $160 \mathrm{~K}$ was significantly less specific than that observed with intact CPSF (Murthy and Manley 1995). As proposed by these authors, the $160-\mathrm{kD}$ polypeptide requires other CPSF subunits to enhance specific binding to the RNA substrate. Therefore, an obvious role for the $30-\mathrm{kD}$ subunit is to cooperate with CPSF $160 \mathrm{~K}$ in the recognition and the binding to the
pre-mRNA. However, in a recently published report on the cloning and characterization of the Drosophila homolog of CPSF 30K, clp, Bai and Tolias (1996) propose a function for this protein as an RNase and suggest a possible involvement in RNA turnover. Therefore, it is intriguing to speculate that the $30-\mathrm{kD}$ subunit may represent the endonuclease responsible for the cleavage step. However, the mutant yeast homolog is only impaired in polyadenylation. A tentative explanation would be an involvement of the protein in both cleavage and polyadenylation and a selective effect of the mutation on only one of the functions. A good candidate for an important, evolutionary conserved role is the second zinc finger, which is extremely conserved in CPSF $30 \mathrm{~K}$ and in its four eukaryotic homologs. Further experiments will determine the role of the different zinc finger repeats and provide insight into the function of this protein.

\section{Materials and methods}

\section{Strains}

The following yeast strains were employed in this study: BMA41 (MATa/ $\alpha$, ade2/ade2, leu2/leu2, ura3/ura3, trp1s/

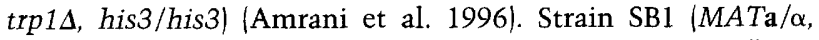
ade2/ade2, leu2/leu2, ura3/ura3, trp1s/trp1A, his3/his3, YTH1/yth1::TRP1) was created by standard gene disruption techniques. Strain SB3 [MATa, ade2, leu2, ura3, trp1A, his3, yth1::TRP1, pHH1-YTH1 [CEN4 URA3 YTH1)] was used as background for plasmid shuffling, originating the strains SB6 [same as SB3 but pFA-YTH1 (CEN4 ADE2 YTH1)] and SB7 [same as SB3 but pFA-yth1-1 (CEN4 ADE2 yth1-1)]. Twohybrid assays were performed with strains Y187 (MAT $\alpha$, ura352, his3, ade2-101, trp1-901, leu2-3,-112, gal4s, gal804, URA3::GAL1-lacZ; Harper et al. 1993] and GC1945 [MATa, ura3-52, his34200, lys2-801, ade2-101, trp1-901, leu2-3,-112, gal4-542, gal80-538, LYS2::GAL1-HIS3, URA3::GAL4 $4_{17 \operatorname{mers}\left(\mathbf{x}_{3}\right)^{-}}$ $C Y C 1_{\text {TATA }}-1 \mathrm{lacZ}, \mathrm{cyh} \mathrm{h}^{\mathrm{2}} \mathrm{]}$.

Peptide microsequencing and $\mathrm{cDNA}$ cloning of the $30-\mathrm{kD}$ polypeptide

Tryptic digestion of purified CPSF [poly(A)-Sepharose pool; Bienroth et al. 1991] and peptide sequencing were performed as described previously (Jenny et al. 1994). The sequences of the two peptides obtained (T21, RVICVNYLVGFCPEGPSCK, and T9, GHLAFLSGQ/ were used to search databanks with the programs FASTA and TFASTA. The human EST NIB2101 containing the two peptides had been sequenced in Dr. J.M. Sikela's laboratory (University of Colorado Health Sciences Center, Denver). A 480-bp HindIII-PvuII fragment of the NIB2101 phagemid was used to screen $1.6 \times 10^{6}$ plaques of a random primed bovine aorta cDNA library in $\lambda$ ZAP II. Hybridization was performed at $42^{\circ} \mathrm{C}$ in $6 \times \mathrm{SSC}, 5 \times$ Denhardt's solution, $1 \%$ SDS, and $100 \mathrm{mg} / \mathrm{ml}$ herring sperm DNA. The duplicate filters were washed once at $55^{\circ} \mathrm{C}$ in $2 \times \mathrm{SSC}, 0.5 \%$ SDS, once at $65^{\circ} \mathrm{C}$ in $1 \times \mathrm{SSC}, 0.5 \%$ SDS, and finally twice at $65^{\circ} \mathrm{C}$ in $0.2 \times \mathrm{SSC}, 0.2 \%$ SDS. Three positive clones were identified (c3, c4.1, and c4.2). Exo III deletions of the longest clone (c4.2) were produced (Erase-a-base system, Promega) and sequenced on an Applied Biosystem 373A sequencer as described previously (Jenny et al. 1994). 
Cloning, disruption, and generation of conditional alleles of the YTHl gene

The YTH1-coding region was amplified by PCR on yeast genomic DNA using the homologous primers $5^{\prime}$-YTH $\left(5^{\prime}\right.$-ATTTGCGGCCGCCATGAGCCTAATTCACCCC-3') and $3^{\prime}$-YTH (5'. CGGAATTCTGAAACTTCACCGTTTATAATT- $\left.3^{\prime}\right)$. The 630bp NotI-EcoRI fragment obtained was subcloned into pBluescript KS (Stratagene) and sequenced on an Applied Biosystem 373A sequencer. To disrupt the YTH1 ORF, a bluntended BgIII fragment of the plasmid pGURT (Jenny et al. 1996), containing the TRP1 gene, was inserted into pBS-YTH1 linearized with NheI-XbaI and filled-in. The resulting construct, in which amino acids 39-120 were replaced by the TRP1 gene, was then transformed into a BMA4l diploid strain. Trp ${ }^{+}$prototrophs were selected, sporulated, and dissected. The spores segregated with a 2 viable: 2 lethal ratio. To confirm that the TRP1 gene had inserted into the YTH1 locus, YTH1/yth1::TRP1 diploids were transformed with a URA3 plasmid carrying the YTH1 clone (pHH1-YTH1). Following sporulation and dissection, $\mathrm{Ura}^{+}$yth1::TRP1 spores were isolated (strain SB4).

To have the YTH1 gene under the control of it own promoter, $\sim 25,000$ colonies of a genomic library derived from strain YBS105, transformed in E. coli XL1-Blue cells (a gift of P. Philippsen, Biozentrum, University of Basel, Switzerland) were screened with the NotI-EcoRI PCR fragment. Three clones were obtained that contained the YTH1 locus. A 940-bp SphI-EcoRI fragment, containing the promoter region and the entire ORF, was cloned into a centromeric vector (pAZ11) and used to transform it into SB3.

To obtain conditional alleles of the YTH1 gene, the EcoRI$S p h I$ genomic fragment, containing the complete ORF, was cleaved at the internal restriction sites DdeI, NheI, and MspI, filled-in, and religated. This step generated three different constructs with a frame-shift mutation at position 20 (pFAYTH1::DdeI), a stop codon at position 120 (pFA-YTH1::NheI), or a frame-shift at position 154 (pFA-YTH1::MspI), respectively. The constructs were transformed into SB3 and 10 colonies for each transformation were replicated on synthetic complete (SC) medium lacking tryptophane and adenine containing 5-fluoroorotic acid to select for the loss of the URA3-marked YTH1 plasmid. After growth for $36 \mathrm{hr}$ at $24^{\circ} \mathrm{C}$ only pFA-YTH1::MspI was able to complement the YTH1 null allele. These cells were then streaked on YPD at $16^{\circ} \mathrm{C}, 24^{\circ} \mathrm{C}, 30^{\circ} \mathrm{C}$, and on YPD containing $3 \%$ formamide (YPDF) at $30^{\circ} \mathrm{C}$ and $37^{\circ} \mathrm{C}$ to test for conditional defects. pFA-YTH1:MspI failed to complement the null allele on YPDF at $30^{\circ} \mathrm{C}$. This allele was designated yth1-1.

\section{Generation of antibodies}

A $1260-\mathrm{bp}-$ long Pst fragment of the complete $30-\mathrm{kD}$ cDNA was subcloned into expression vector pRSETA (Invitrogen) and then transformed into strain BL21 (DE3pLysS). Cultures $(500 \mathrm{ml})$ were induced at an $\mathrm{OD}_{600}=0.8$ with $1 \mathrm{~mm}$ isopropyl-thiogalactoside for $3 \mathrm{hr}$. Bacterial extracts were prepared under denaturing conditions according to the Qiagen Expressionist manual. The His-tagged fusion protein was applied on a $\mathrm{Ni}^{2+}$ nitriloacetic acid agarose column and eluted with a $\mathrm{pH}$ gradient according to the manufacturer's instructions (Qiagen). The recombinant protein was separated on a $12 \%$ SDS-polyacrylamide gel and eluted overnight in Tris-glycine/ $0.1 \%$ SDS buffer. A rabbit was injected with $\sim 100 \mu \mathrm{g}$ recombinant protein emulsified with Freund adjuvant. After five booster injections the rabbit was terminally bled and antiserum prepared according to standard procedure.

To express recombinant Ythl protein, a PCR NotI (blunt)-
EcoRI fragment encoding the complete ORF was subcloned into pRSETB (Invitrogen) linearized with PvuII-EcoRI. The plasmid was transformed into strain BL21 (DE3pLysS). Purification of the recombinant protein and the immunization of the rabbit were performed as described above. The antibody was affinity purified on immobilized Yth1 protein according to standard procedures (Pringle et al. 1991).

Rabbit polyclonal antibodies directed against CPSF 160K were obtained as described (Jenny and Keller 1995).

\section{Immunodepletion of HeLa cell nuclear extracts}

HeLa cell nuclear extracts were prepared as described previously (Rüegsegger et al. 1996). For each batch of depleted extract $2 \times 80 \mu \mathrm{l}$ of protein A-sepharose (packed volume) were incubated overnight at $4{ }^{\circ} \mathrm{C}$ with $30 \mu \mathrm{l}$ of either antiserum or preimmune serum in $400 \mu \mathrm{IPP}_{500}(500 \mathrm{mM} \mathrm{NaCl}, 10 \mathrm{~mm}$ Tris- $\mathrm{HCl}$ at $\mathrm{pH} 7.9,0.1 \% \mathrm{NP}-40$ ). The beads were washed three times in $1 \mathrm{ml}$ of $\mathrm{IPP}_{150}$. After the final wash, the supernatant was removed completely to avoid extract dilution. HeLa nuclear extract $(250 \mu \mathrm{l})$ was added to the first batch of beads and rotated for $1.5 \mathrm{hr}$ at $4^{\circ} \mathrm{C}$. After a brief centrifugation, the supernatant was transferred to an eppendorf tube containing fresh beads and the incubation step was repeated. The supernatants were then devided in small aliquots and frozen in liquid nitrogen. Aliquots were analyzed by immunoblotting to assess the efficiency of depletion. Anti-30K and anti-100K antibodies could deplete $50 \%-60 \%$ of the CPSF subunits. The immunoprecipitated proteins were eluted in $1 \times$ SDS-sample buffer for $2 \mathrm{~min}$ at $95^{\circ} \mathrm{C}$. One-third of the eluate was fractionated on an $8 \%$ SDS-polyacrylamide gel to allow efficient transfer of the $160 \mathrm{~K}$ subunit and blotted onto nitrocellulose.

\section{Cleavage and polyadenylation assays}

The RNA substrates used in this study were prepared from the following plasmids: pSP6L3 contains the polyadenylation signal of the adenovirus 2 major late transcription unit; pSP6L3pre is derived from the previous construct but terminates one nucleotide upstream of the natural polyadenylation site; pG4-CYC1 contains the $3^{\prime}$ untranslated region of the iso-1-cytochrome $\mathrm{C}$ gene (Minvielle-Sebastia et al. 1994); pG4-CYClpre is derived from the previous construct by insertion of an NdeI site just distal to the cleavage site (Preker et al. 1995). pSP6L3 was linearized with RsaI, pSP6-L3pre with DraI, pG4-CYC1 with EcoRI and pG4-CYClpre with NdeI. Transcriptions were performed according to standard procedures.

Polyadenylation assays with HeLa cell nuclear extracts were performed on L3pre RNA essentially as described previously (Bienroth et al. 1991). Cleavage reactions were performed in 25 - $\mathrm{ll}$ reactions containing $5 \mathrm{~mm}$ DTT, $0.025 \%$ (vol/vol) NP-40, $50 \mathrm{~mm}$ creatine phosphate (Boehringer Mannheim $\mathrm{GmbH}$ ), $6.5 \%$ (wt/vol) polyvinyl alcohol, $0.5 \mathrm{U} / \mathrm{\mu l}$ of RNAguard (Pharmacia), $0.025 \mathrm{mg} / \mathrm{ml}$ of creatine kinase (Boehringer Mannheim $\mathrm{GmbH}), 12.5 \mathrm{~mm}$ cordycepin 5 '-triphosphate (Boehringer Mannheim $\mathrm{GmbH}$ ), $3.75 \mathrm{mM} \mathrm{MgCl}_{2}, 15$ fmoles of L3 RNA, 30\% (vol/ vol) nuclear extract. The reactions were incubated for $1 \mathrm{hr}$ at $30^{\circ} \mathrm{C}$. Yeast extracts were prepared according to Ansari and Schwer (1995). Yeast processing assays were performed in $25 \mu l$ at $30^{\circ} \mathrm{C}$ using $30 \%$ (vol/vol) extract and $20-40$ fmoles of premRNA as described previously (Minvielle-Sebastia et al. 1994).

In vitro translation, $R N A$ binding, and coimmunoprecipitation assays

A construct containing the complete ORF of the $30-\mathrm{kD}$ protein was made by subcloning into pBluescript KS(-) (Stratagene) a 
PstI-PvuII fragment of the clone c4.1. A construct encoding the $30-\mathrm{kD}$ subunit, in which the last 46 amino acids coding for the zinc knuckle motif had been deleted, was generated by cloning a PstI-BspMI fragment of clone $c 4.1$ in pBluescript linearized with PstI-SmaI. Both these constructs were linearized with BamHI and transcribed with T3 RNA polymerase. To construct a chimeric Ythl protein carrying the zinc knuckle motif at its carboxyl terminus, we amplified by PCR a 141-bp SmaI-EcoRI fragment encoding the last 46 amino acids of the $30-\mathrm{kD}$ protein with the primers $5^{\prime} \mathrm{ZK} 15^{\prime}$-TCCCCCGGGTCATGCGAGTCAA-3') and $3^{\prime} \mathrm{ZK}$ (5'-CCGGAATTCTCACTGTCCGCTGAG$\left.3^{\prime}\right)$. This fragment was ligated to a $570-\mathrm{bp} Y T H 1$ fragment (amino acids 1-190) derived from the digestion of pBS-YTHl with BstNI. This construct and the plasmid-encoding Ythlp (pBS-YTH1) were linearized with NotI and transcribed with T7 RNA polymerase (Stratagene). The RNAs coding for the $30 \mathrm{~K}$ and for the $30 \mathrm{~K} \Delta$ proteins were translated in rabbit reticulocyte lysate (Promega), whereas YTH1 and YTH1-zk were translated in wheat germ extract (Promega) in presence of $10 \mathrm{mM}$ and 50 $\mathrm{mM} \mathrm{K}$-acetate, respectively. The amount of protein obtained in each in vitro translation reaction was quantified by dividing the amount incorporated $\left[{ }^{35} \mathrm{~S}\right]$ methionine by the number of methionine residues present in each protein.

Poly $(\mathrm{G})$ and poly $(\mathrm{Cl}$ were coupled to $\mathrm{CNBr}$-activated sepharose according to the manufacturer instructions (Pharmacia). Poly|A $)$-, poly(U)-, p(I/C)-Sepharose and single-stranded DNA cellulose were purchased from Pharmacia. Approximately $20 \mu \mathrm{l}$ of resin, equilibrated in binding buffer $\left(\mathrm{BB}_{100}\right)(100 \mathrm{mM} \mathrm{NaCl}, 50$ $\mathrm{mM}$ Tris- $\mathrm{HCl}$ at $\mathrm{pH} 7.9,0.02 \% \mathrm{NP}-40$ ), was mixed with $1-8 \mu \mathrm{l}$ of translation reaction depending on the concentration of the protein (corresponding to 2-4 fmoles of protein depending on the experiment) and $300 \mu \mathrm{l}$ of $\mathrm{BB}_{100}$. The reactions were rotated for $1 \mathrm{hr}$ at $4^{\circ} \mathrm{C}$, then washed three times with $1 \mathrm{ml}$ of the same buffer. The bound protein was eluted in $20 \mu$ l of protein sample buffer and loaded on a $12 \%$ SDS-PAGE. The gel was incubated in $1 \mathrm{M} \mathrm{Na}$-salycilate, dried, and exposed to film.

The coimmunoprecipitation experiments were performed essentially as described previously (Preker et al. 1995): anti-Fiplp, anti-Paplp, and a mixture of anti-Rnal4p and anti-Rna15p antibodies were coupled to protein-A sepharose equilibrated in IPP $_{150}$. After extensive washes the corresponding recombinant protein was added. The immobilized proteins were incubated with in vitro-translated, radio-labeled Ythl protein. The bound proteins were eluted by heating $5 \mathrm{~min}$ at $95^{\circ} \mathrm{C}$ in protein sample buffer, fractionated on a $12 \%$ SDS-PAGE and visualized by autoradiography. To quantitate the bound protein, the gel was exposed to a PhosphorImager screen for $2 \mathrm{hr}_{\text {; }}$ the screen was then scanned with a PhosphorImager 425 (Molecular Dynamics) using the ImageQuant 3.3 program. The amount of bound protein was determined with the IPLabGel software (version 1.5, Signal Analytics Corp.).

\section{Two-hybrid assays}

The plasmids encoding fusions of YTH1 and FIP1 to the GAL4 DNA-binding domain and the GAL4 activation domain were constructed by in-phase insertion of the respective ORFs in pAS2 $\Delta \Delta$ (pAS2 deleted for the CYH2 gene and the HA epitope) and pACT2 vectors (a gift from P. Legrain, Institut Pasteur, Paris, France; Fromont-Racine et al. 1997). The ORFs were generated by PCR using oligonucleotides containing at their $5^{\prime}$ extremity the adequate restriction sites. A 1004-bp NcoI-BgIII fragment containing the FIP1 ORF was generated using the primers FIP5 (5'-CATGCCATGGCAATGAGCTCCAGTGAAGA$\left.3^{\prime}\right)$ and FIP3 (5'-GAAGATC'TTCATTTCGAATTTTGATTTTG-3'). A 647-bp NcoI-BamHI YTH1 fragment was amplified by using the primers YTH5 (5'-CATGCCATGGCAATGAGCCTAATTCACC$\left.3^{\prime}\right)$ and YTH3 (5'-CGGGATCCTCAAACTTCACCGTTTAT$\left.3^{\prime}\right)$. These fragments were inserted in the vectors at the $N$ coI and $B a m H I$ sites. The PAP1 constructs were obtained by insertion of $B a m H I-B a m H I$ fragments issued from the pGBT and pGAD constructs as described in Preker et al. (1995). No sequence errors were observed after sequencing of the inserted ORFs. Two-hybrid assays were performed by mating Y187 and CG1945 strains. Each strain was transformed with either the pAS2 or pACT2 vector constructs and screened for its ability to grow at $30^{\circ} \mathrm{C}$ on SC medium lacking tryptophane or leucine. The transformants were then mated. The diploid strains containing both types of plasmids were selected on SC plates lacking leucine and tryptophane. The ability to express the reporter gene HIS 3 was tested on SC plates lacking leucine, tryptophane, and histidine but containing $25 \mathrm{~mm} 3$-aminotriazole. $\beta$-Galactosidase activity was assayed by filter lift assays (Chevray and Nathans 1992). Quantitative assays were performed as described previously (Preker et al. 1995).

\section{Acknowledgments}

We thank Dr. J.M. Sikela for the gift of the human cDNA clone NIB2101. We are grateful to Paul Jenö for obtaining the sequence of the tryptic peptides, Horst Pick and P. Philippsen for the yeast genomic library and P. Preker for the anti-Fiplp antibodies and the PF I fraction. We also thank K. Beyer, $M$. O'Connell, P. Preker, and E. Wahle for helpful suggestions concerning the manuscript. This work was supported by the European Union Human Capital Mobility Program, the Kantons of Basel, the Swiss National Science Foundation. S.M.L.B. was supported by a Human Capital Mobility fellowship.

The publication costs of this article were defrayed in part by payment of page charges. This article must therefore be hereby marked "advertisement" in accordance with 18 USC section 1734 solely to indicate this fact.

\section{References}

Amrani, N., M.-E. Dufour, N. Bonneaud, and F. Lacroute. 1996. Mutations in STS1 suppress the defect in 3' mRNA processing caused by the rna15-2 mutation in S. cerevisiae. Mol. Gen. Genet. 252: 552-562.

Ansari, A. and B. Schwer. 1995. SLU7 and a novel activity, SSF1, act during the PRP16-dependent step of yeast pre-mRNA splicing. EMBO J. 14: 4001-4009.

Arning, S., P. Grüter, G. Bilbe, and A. Krämer. 1996. Mammalian splicing factor SF1 is encoded by variant cDNAs and binds to RNA. RNA 2: 794-810.

Ashburner, M. 1990. Puffs, genes and hormones revisited. Cell 61: $1-3$.

Bai, C. and P.P. Tolias. 1996. Cleavage of RNA hairpins by a developmentally regulated $\mathrm{CCCH}$ zinc finger protein. Mol. Cell. Biol. 16: 6661-6667.

Berg, J.M. and Y. Shi 1996. The galvanization of biology: A growing appreciation for the roles of zinc. Science 271: 10811085.

Bienroth, S., E. Wahle, C. Suter-Crazzolara, and W. Keller. 1991. Purification of the cleavage and polyadenylation factor involved in the 3 '-processing of messenger RNA precursors. $\%$. Biol. Chem. 266: 19768-19776.

Cavaloc, Y., M. Popielarz, J.-P. Fuchs, R. Gattoni, and J. Stévenin. 1994. Characterization and cloning of the human splicing factor 9G8: A novel $35 \mathrm{kDa}$ factor of the serine/ arginine protein family. EMBO J. 13: 2639-2649. 
Chanfreau, G., S.M. Noble, and C. Guthrie. 1996. Essential yeast protein with unexpected similarity to subunits of mammalian Cleavage and Polyadenylation Specificity Factor (CPSF). Science 274: 1511-1514.

Chen, J. and C. Moore. 1992. Separation of factors required for cleavage and polyadenylation of yeast pre-mRNA. Mol. Cell. Biol. 12: 3470-3481.

Chevray, P.M. and D. Nathans. 1992. Protein interaction cloning in yeast: Identification of mammalian proteins that react with the leucine zipper of Jun. Proc. Natl. Acad. Sci. 89: 5789-5793.

Doolittle, W.F. and A. Stoltzfus. 1993. Genes-in-pieces revisited. Nature 361: 403.

DuBois, R.N., M.W. McLane, K. Ryder, L.F. Lau, and D. Nathans. 1990. A growth factor-inducible nuclear protein with a novel cysteine/histidine repetitive sequence. J. Biol. Chem. 265: 19185-19191.

Fields, S. and R. Sternglanz. 1994. The two-hybrid system: An assay for protein-protein interactions. Trends Genet. 10: 286-292.

Frank, D. and C. Guthrie. 1992. An essential splicing factor, SLU7, mediates 3' splice site choice in yeast. Genes \& Dev. 6: $2112-2124$

Fridell, R.A. and L.L Searles. 1994. Evidence for a role of the Drosophila melanogaster suppressor of sable gene in premRNA splicing. Mol. Cell. Biol. 14: 859-867.

Fromont-Racine, M., J.-C. Rain, and P. Legrain. 1997. Toward a functional analysis of the yeast genome through exhaustive two-hybrid screens. Nature Genet. (in press).

Gaiano, N., A. Amsterdam, M. Allende, and N. Hopkins. 1996. Insertional mutagenesis and rapid cloning of essential genes in zebrafish. Nature 383: 829-832.

Gilbert, W. 1985. Genes-in-pieces revisited. Science 228: 823824.

Gilmartin, G.M. and J.R. Nevins. 1991. Molecular analyses of two poly(A) site-processing factors that determine the recognition and efficiency of cleavage of the pre-mRNA. Mol. Cell. Biol. 11: 2432-2438.

Gilmartin, G.M., E.S. Fleming, J. Oetjen, and B.R. Graveley. 1995. CPSF recognition of an HIV-1 mRNA 3 '-end processing enhancer: Multiple sequence contacts involved in poly(A) site definition. Genes \& Dev. 9: 72-83.

Gunderson, S.I., K. Beyer, G. Martin, W. Keller, W.C. Boelens, and I.W. Mattaj. 1994. The human U1A snRNP protein regulates polyadenylation via a direct interaction with poly(A) polymerase. Cell 76: 531-541.

Guo, Z. and F. Sherman. 1996. 3'-end-forming signals of yeast mRNA. Trends Biochem. Sci. 21: 477-480.

Harper, J.W., G.R. Adami, N. Wei, K. Keyomarsi, and S.J. Elledge. 1993. The p21 Cdk-interacting protein Cipl is a potent inhibitor of G1 cyclin-dependent kinases. Cell 75: 805-816.

Jacks, T., K. Townsley, H.E. Varmus, and J. Majors. 1987. Two efficient ribosomal frameshifting events are required for synthesis of mouse mammary tumor virus gag-related polyproteins. Proc. Natl. Acad. Sci. 84: 4298-4302.

Jenny, A. and W. Keller. 1995. Cloning of the $160 \mathrm{kDa}$ subunit of the bovine cleavage and polyadenylation specificity factor. Nucleic Acids Res. 23: 2629-2635.

Jenny, A., H.-P. Hauri, and W. Keller. 1994. Characterization of cleavage and polyadenylation specificity factor and cloning of its 100-kilodalton subunit. Mol. Cell. Biol. 14: 8183-8190.

Jenny, A., L. Minvielle-Sebastia, P.J. Preker, and W. Keller. 1996. Sequence similarity between the $73 \mathrm{kDa}$ protein of mammalian CPSF and a subunit of yeast Polyadenylation Factor I. Science 274: 1514-1517.
Keller, W., S. Bienroth, K.M. Lang, and G. Christofori. 1991. Cleavage and polyadenylation factor $(\mathrm{CPF})$ specifically interacts with the pre-mRNA $3^{\prime}$ processing signal AAUAAA. EMBO J. 10: 4241-4249.

Manley, J. and N.J. Proudfoot. 1994. RNA 3' ends. Formation and function-meeting review. Genes \& Dev. 8: 259-264.

Manley, J.L. and Y. Takagaki. 1996. The end of the messageAnother link between yeast and mammals. Science 274: 1481-1482.

Mello, C.C., C. Schubert, B. Draper, W. Zhang, R. Lobel, and J.R. Priess. 1996. The PIE-1 protein and germline specification in C. elegans embryos. Nature 382: 710-712.

Minvielle-Sebastia, L., B. Winsor, N. Bonneaud, and F. Lacroute. 1991. Mutations in the yeast RNA14 and RNA15 genes result in an abnormal mRNA decay rate; Sequence analysis reveals an RNA-binding domain in the RNA15 protein. $M o l$. Cell. Biol. 11: 3075-3087.

Minvielle-Sebastia, L., P. Preker, and W. Keller. 1994. RNA14 and RNA15 proteins as components of a yeast pre-mRNA 3 '-end processing factor. Science 266: 1702-1705.

Mohler, J., N. Weiss, S. Murli, S. Mohammadi, K. Vani, G. Vasilakis, C.H. Song, A. Epstein, T. Kuang, J. English, and D. Cherdak. 1992. The embryonically active gene, unkempt, of Drosophila encodes a cys3his finger protein. Genetics 131: 377-388.

Murthy, K.G.K. and J.L. Manley, 1992. Characterization of the multisubunit cleavage-polyadenylation specificity factor from calf thymus. J. Biol. Chem. 267: 14804-14811.

- 1995. The $160-\mathrm{kD}$ subunit of human cleavage-polyadenylation specificity factor coordinates pre-mRNA 3 '-end formation. Genes \& Dev. 9: 2672-2683.

Preker, P.J., J. Lingner, L. Minvielle-Sebastia, and W. Keller. 1995. The FIP1 gene encodes a component of a yeast premRNA polyadenylation factor that directly interacts with poly(A) polymerase. Cell 81: 379-389.

Preker, P.J., M. Ohnacker, L. Minvielle-Sebastia, and W. Keller. 1997. A multisubunit 3 '-end processing factor from yeast containing poly(A) polymerase and homologues of the subunits of mammalian cleavage and polyadenylation specificity factor. $E M B O T$. (in press).

Pringle, J.R., A.E.M. Adams, D.G. Drubin, and B.K. Haarer. 1991. Immunofluorescence methods for yeast. Methods Enzymol. 194: 565-602.

Rajavashisth, T.B., A.K. Taylor, A. Andalabi, K.L. Svenson, and A.J. Lusis. 1989. Identification of a zinc finger protein that binds to the sterol regulatory element. Science 245: 640-643.

Rüegsegger, U., K. Beyer, and W. Keller. 1996. Purification and characterization of human cleavage factor $I_{m}$ involved in $3^{\prime}$ end processing of messenger RNA precursors. J. Biol. Chem. 271: 6107-6113.

Sambrook, J., E.F. Fritsch, and T. Maniatis. 1989. Molecular cloning: A laboratory manual. 2nd ed. Cold Spring Harbor Laboratory Press, Cold Spring Harbor, NY.

Schwartz, D.E., R. Tizard, and T. Gilbert. 1983. Nucleotide sequence of rous sarcoma virus. Cell 32: 853-869.

South, T.L., P.R. Blake, R.C. Sowder, L.O. Arthur, L.E. Henderson, and M.F. Summers. 1990. The nucleocapsid protein isolated from HIV-1 particles binds zinc and forms retroviraltype zinc fingers. Biochemistry 29: 7786-7789.

Stumpf, G. and H. Domdey. 1996. Dependence of yeast premRNA $3^{\prime}$-end processing on CFT1: A sequence homolog of the mammalian AAUAAA binding factor. Science 274: $1517-1520$.

Takagaki, Y. and J.L. Manley. 1994. A polyadenylation factor subunit is the human homolog of the Drosophila suppressor of forked protein. Nature 372: 471-474. 
Barabino et al.

Takagaki, Y., L.C. Ryner, and J.L. Manley. 1989. Four factors are required for 3 '-end cleavage of pre-mRNAs. Genes \& Dev. 3: $1711-1724$.

Theunissen, O., F. Rudt, U. Guddat, H. Mentzel, and T. Pieler. 1992. RNA and DNA binding zinc fingers in Xenopus TFIIIA. Cell 71: 679-690.

Voelker, R.A., W. Gibson, J.P. Graves, J.F. Sterling, and M.T. Eisenberg. 1991. The Drosophila suppressor of sable gene encodes a polypeptide with regions similar to those of the RNA-binding proteins. Mol. Cell. Biol. 11: 894-905.

Wahle, E. 1991. A novel poly(A)-binding protein acts as a specificity factor in the second phase of messenger RNA polyadenylation. Cell 66: 759-768.

. 1995. 3'-end cleavage and polyadenylation of mRNA precursors. Biochim. Biophys. Acta 1261: 183-194.

Wahle, E. and W. Keller. 1992. The biochemistry of 3 '-end cleavage and polyadenylation of messenger RNA precursors. Annu. Rev. Biochem. 61: 419-440.

. 1996. The biochemistry of polyadenylation. Trends Biochem. Sci. 21: 247-250.

Wain-Hobson, S., P. Sonigo, O. Danos, S. Cole, and M. Alizon. 1985. Nucleotide sequence of the AIDS virus. Cell 40: 9-17.

Zhang, M., P.D. Zamore, M. Carmo-Fonseca, A.I. Lamond, and M. Green. 1992. Cloning and intracellular localization of the U2 nuclear ribonucleoprotein auxiliary factor small subunit. Proc. Natl. Acad. Sci. 89: 8769-8773. 


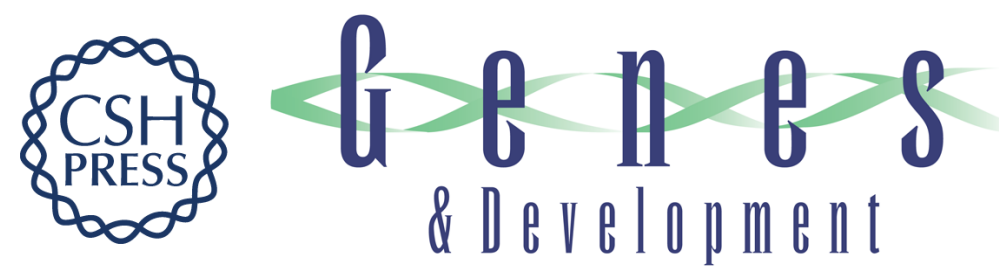

\section{The 30-kD subunit of mammalian cleavage and polyadenylation specificity factor and its yeast homolog are RNA-binding zinc finger proteins.}

S M Barabino, W Hübner, A Jenny, et al.

Genes Dev. 1997, 11:

Access the most recent version at doi:10.1101/gad.11.13.1703

References This article cites 53 articles, 29 of which can be accessed free at:

http://genesdev.cshlp.org/content/11/13/1703.full.html\#ref-list-1

License

Email Alerting Service

Receive free email alerts when new articles cite this article - sign up in the box at the top right corner of the article or click here.

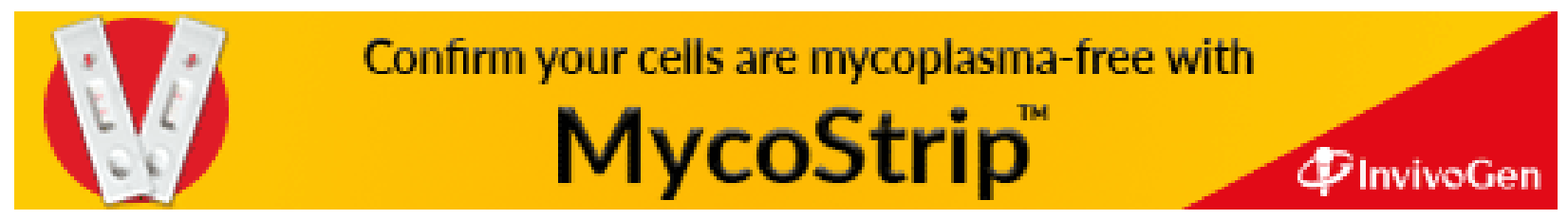

